\title{
Effects of intramammary infusion of sage (Salvia officinalis) essential oil on milk somatic cell count, milk composition parameters and selected hematology and serum biochemical parameters in Awassi sheep with subclinical mastitis
}

\author{
Myassar O. Alekish ${ }^{1}$, Zuhair B. Ismail ${ }^{1}$, Mofleh S. Awawdeh ${ }^{2}$ and Shoroq Shatnawi ${ }^{3}$
}

1. Department of Veterinary Clinical Sciences, Faculty of Veterinary Medicine, Jordan University of Science and Technology, Irbid, Jordan; 2. Department of Veterinary Pathology and Public Health, Faculty of Veterinary Medicine, Jordan University of Science and Technology, Irbid, Jordan; 3. Private Large Animals Practice, Bushra, Jordan. Corresponding author: Myassar O. Alekish, e-mail: moalekish@just.edu.jo

Co-authors: ZBI: zuhair72@just.edu.jo, MSA: mawawdeh@just.edu.jo, SS: Shoroq_vet@yahoo.com Received: 11-04-2017, Accepted: 06-07-2017, Published online: 10-08-2017

doi: 10.14202/vetworld.2017.895-900 How to cite this article: Alekish MO, Ismail ZB, Awawdeh MS, Shatnawi S (2017) Effects of intramammary infusion of sage (Salvia officinalis) essential oil on milk somatic cell count, milk composition parameters and selected hematology and serum biochemical parameters in Awassi sheep with subclinical mastitis, Veterinary World, 10(8): 895-900.

\begin{abstract}
Aim: The aims of this study were to evaluate the effects of intramammary infusion of sage (Salvia officinalis) essential oil (EO) on milk somatic cell count (SCC), milk composition parameters and selected hematology and serum biochemical parameters in 20 Awassi ewes affected with subclinical mastitis.

Materials and Methods: The dried leaves of sage were used to extract the EO by hydrodistillation. The minimum inhibitory concentration (MIC) and minimum bactericidal concentration (MBC) of sage EO against Staphylococcus aureus were determined by the broth dilution method. Ewes were divided randomly into three main groups and received one of the following treatments; Group $1(\mathrm{n}=5)$ : Dimethyl sulfoxide (DMSO) alone ( $5 \mathrm{ml} ; 0.2 \mathrm{ml}$ of DMSO in $4.8 \mathrm{ml}$ of saline), Group $2(\mathrm{n}=5)$ : Amoxicillin alone $(3 \mathrm{ml})$, and Group $3(\mathrm{n}=10)$ : Sage EO $(5 \mathrm{ml}$ of sage EO solution $[0.2 \mathrm{ml} \mathrm{DMSO}+1 \mathrm{ml}$ $\mathrm{EO}+3.8 \mathrm{ml}$ sterile saline]). All treatments were administered by intramammary infusion into each teat twice per day for 3 consecutive days. Milk samples for SCC and milk components determination and whole blood samples for hematology and serum biochemical analyses were collected before treatment (T0) and at 24 (T24) and 48 (T48) h after the last treatment.

Results: The MIC and MBC of sage EO against S. aureus were $12.5 \%$ and $6.1 \%$, respectively. SCC was decreased significantly $(\mathrm{p}<0.05)$ at T24 and T48 $\mathrm{h}$ in sage EO and amoxicillin treated groups. Milk fat and lactose were increased significantly $(\mathrm{p}<0.05)$ in sage EO and amoxicillin treated ewes while no significant changes were observed in the percentages of solidsnot-fat, protein and total solids. No significant effects of sage EO treatment on any of the hematology or serum biochemical parameters were observed. There were no local or systemic side effects observed in any of the treated ewes. However, further clinical trials are warranted to determine safety and possible withdrawal times in milk before its recommendation for use in organic operations.
\end{abstract}

Conclusion: In this study, the intramammary infusion of sage EO to ewes affected with subclinical mastitis resulted in a significant decrease in SCC $24 \mathrm{~h}$ and $48 \mathrm{~h}$ posttreatment. In addition, milk fat and lactose were increased in animals that received the EO as well as in those treated with the antibiotic.

Keywords: antibiotics, alternative treatment, Awassi sheep, mastitis.

\section{Introduction}

Mastitis is a common and costly disease affecting all milk producing animals [1]. The disease has important economic and animal welfare impacts. Economic losses are mainly due to costs of veterinary care and drugs, loss of production, death or culling of animals and reduced milk price due to poor quality [2]. Mastitis, whether it is clinical or subclinical is known to negatively affect udder tissues, productivity and milk constituents

Copyright: Alekish, et al. Open Access. This article is distributed under the terms of the Creative Commons Attribution 4.0 International License (http://creativecommons.org/licenses/ by/4.0/), which permits unrestricted use, distribution, and reproduction in any medium, provided you give appropriate credit to the original author(s) and the source, provide a link to the Creative Commons license, and indicate if changes were made. The Creative Commons Public Domain Dedication waiver (http:// creativecommons.org/publicdomain/zero/1.0/) applies to the data made available in this article, unless otherwise stated. such as casein, lactose, and fat further contributing to the economic burden on farmers [3]. Mastitis is also known to seriously impact the general health and well-being of animals causing significant animal welfare concerns impacting consumer and public perspectives.

Antibacterial agents have been the mainstay of mastitis treatment and prevention programs for decades. The use of antibacterial agents has been accompanied by the appearance of resistant strains of common bacterial species in dairy animals [4]. This rising concern has led to the urgency of finding new and innovative treatment options for mastitis worldwide. In the past few decades, a large quantity of research has been focused on characterizing the antibacterial effects of different herbs and aromatic plants and many other natural substances for the treatment of different animal diseases including mastitis $[5,6]$. 
Sage (Salvia officinalis) is a common herb that can grow wildly or in cultivation. It has been long known for its broad medicinal properties including anti-inflammatory, antiseptic, and antibacterial effects. The active component of sage essential oil (EO) is 1, 8-cineole which was particularly found affective against Escherichia coli and Staphylococcus aureus $[7,8]$. The objectives of this study were to evaluate the effects of intramammary infusion of sage EO on milk somatic cell count (SCC), various milk component parameters and selected hematology and serum biochemical parameters in Awassi sheep affected with subclinical mastitis.

\section{Materials and Methods}

\section{Ethical approval}

This to declare that the Animal Care and Use Committee (ACUC) at Jordan University of Science and Technology has approved that all adequate measures were taken to minimize pain or discomfort to all the animals included in this study. The experiment was carried out in accordance with the Guidelines laid down by the International Animal Ethics Committee and in accordance with local laws and regulations.

\section{Sage EO extraction}

The EO of sage was extracted by hydrodistillation using Clevenger's apparatus. Briefly, freshly collected sage plants from northern Jordan were left to air dry. The leaves were then weighed and mixed with distilled water at a rate of $1 \mathrm{~g}$ sage leaves per $6.81 \mathrm{ml}$ of distilled water. The mixture was then heated to $100^{\circ} \mathrm{C}$ for $3 \mathrm{~h}$. The EO was then collected. The extracted oil was dehydrated by adding a few drops of sodium sulfate ( $0.5 \mathrm{~g}$ for $4 \mathrm{ml} \mathrm{EO}$ ) and stored at $-20^{\circ} \mathrm{C}$ until used.

\section{Minimum inhibitory concentration (MIC) and mini- mum bactericidal concentration (MBC)}

The MIC of sage EO was performed against previously isolated pathogenic strains of $S$. aureus from field cases of mastitis. MIC was determined by the broth dilution method in Muller-Hinton broth. Briefly, sage EO was first dissolved in $80 \%(\mathrm{v} / \mathrm{v})$ dimethyl sulfoxide (DMSO) solution. As DMSO is considered to have an antibacterial effect so this study tested different concentrations to avoid the effect of DMSO showed the least effect. To determine the best DMSO dilution, different concentrations were made and smeared on an already streaked bacterial culture plates using $S$. aureus field strain and incubated at $37^{\circ} \mathrm{C}$ for $24 \mathrm{~h}$. DMSO concentration $(0.2 \mathrm{ml}$ of DMSO plus $4.8 \mathrm{ml}$ of distilled water) that induced least bacterial inhibition was chosen. This was called the stock solution or solution I. Different concentrations of sage EO were then obtained using distilled water as follows: $100 \%$ (Solution I), 50\%, 25\%, 12.5\%, 6.2\%, and 3.1\% $(\mathrm{v} / \mathrm{v})$, all called solution II.

To determine the MIC, $1 \mathrm{ml}$ of $S$. aureus inoculum $\left(10^{6} \mathrm{UFC} / \mathrm{ml}\right)$ and $1 \mathrm{ml}$ of each EO dilutions (Solution II) were added to $2 \mathrm{ml}$ of Muller-Hinton broth. Positive control was prepared by adding $1 \mathrm{ml}$ of $S$. aureus inoculum to $3 \mathrm{ml}$ of Muller-Hinton broth. Negative control was prepared by adding $1 \mathrm{ml}$ of $S$. aureus inoculum to $1 \mathrm{ml}$ of DMSO and $2 \mathrm{ml}$ of Muller-Hinton broth. After $24 \mathrm{~h}$ of incubation at $37^{\circ} \mathrm{C}$, MIC was determined as the lowest concentration of the EO inhibiting visible bacterial growth.

To determine the minimum bactericidal concentration, $10 \mu \mathrm{l}$ of bacterial inoculum was taken aseptically from tubes that had not presented visible turbidity and was spread on blood agar plates and incubated at $37^{\circ} \mathrm{C}$ for $24 \mathrm{~h} \mathrm{[9].} \mathrm{The} \mathrm{MBC} \mathrm{was} \mathrm{consid-}$ ered as the lowest concentration of EO that allowed $<0.1 \%$ of the original inoculum treated with the EO to grow on the surface of the blood agar.

\section{Dosage calculations and preparation}

The effective dose was considered 10 times the MIC [10,11]. Dosage was, therefore, prepared by adding $0.2 \mathrm{ml}$ of DMSO to $1 \mathrm{ml}$ of $12.5 \%$ sage EO solution. The total volume was then made to $5 \mathrm{ml}$ by mixing with $3.8 \mathrm{ml}$ of sterile saline. The prepared dose was then injected into each teat at $12 \mathrm{~h}$ intervals after milking, for 3 consecutive days following the appropriate aseptic preparation of the teat.

\section{Animals and study design}

A total of 20 lactating ewes aged between 2 and 5 years, located in Al-Mafraq Governments of Jordan were used in this study. Before the enrollment in the study, all ewes were subjected to a complete physical examination including udder palpation. Milk samples were then collected from each ewe, and California mastitis test (CMT) was performed.

Only ewes are suffering from subclinical mastitis based on a positive CMT and SCC more than 250,000 cells $/ \mathrm{ml}$ were included in the study. Enrolled ewes were divided randomly into three main groups and received one of the following treatments; Group 1 $(n=5)$ : DMSO alone, Group $2(n=5)$ : Amoxicillin alone, and Group $3(n=10)$ : Sage EO. In the DMSO group, each ewe received $5 \mathrm{ml}$ of DMSO $(0.2 \mathrm{ml}$ of DMSO in $4.8 \mathrm{ml}$ of saline) in each udder at $12 \mathrm{~h}$ intervals for 3 consecutive days. In the amoxicillin group, each ewe received $3 \mathrm{ml}$ tube of an intramammary preparation (Synulox, Pfizer Animal Health, UK) in each udder half at $12 \mathrm{~h}$ intervals for 3 consecutive days. In Groups 3, sage EO solution $(0.2 \mathrm{ml}$ $\mathrm{DMSO}+1 \mathrm{ml} \mathrm{EO}+3.8 \mathrm{ml}$ sterile saline) was injected into each udder half at $12 \mathrm{~h}$ intervals for 3 consecutive days.

All ewes were closely monitored after infusion for immediate adverse reactions and were kept under observation for the next 5 days.

\section{Milk and blood samples collection}

Milk samples were collected from all ewes with positive CMT and placed in test tubes for SCC and milk constituent analyses. Milk samples were collected before the treatment (T0) and at 24 (T24) and 48 (T48) $\mathrm{h}$ after the last EO administration. Milk 
samples were collected according to the standard procedures of International Dairy Federation [12]. In addition, whole blood samples were collected before the treatment (T0) and at $48 \mathrm{~h}$ after the last EO administration. Blood was collected via jugular vein puncture and placed in plain test tubes and EDTA-containing tubes for serum biochemistry and hematology analyses, respectively. All samples were transported to the laboratory in ice box and tested within $2 \mathrm{~h}$.

\section{SCC}

SCC was determined by spreading $10 \mu 1$ of milk on $1 \mathrm{~cm}^{2}$ area of glass slide. Slides were left to air dry before they were stained using Newman-lambert stain. Stained slides were examined under light microscopy, and somatic cells were counted manually as described previously [13].

\section{Milk constituents}

Milk composition parameters including fat, protein, solids, solid-not-fat (SNF) and lactose were measured automatically (Milko scope julie c8; Scope Electric, Regensburg, Germany) according to the manufacturer's instructions.

\section{Hematology and serum biochemical analyses}

Whole blood samples were collected from the jugular vein and placed in plain test tubes and EDTAcontaining tubes before the experiment (T0) and $48 \mathrm{~h}$ (T48) after the last EO administration. Samples were transported in ice box to the laboratory for hematology and blood chemistry. Hematology analysis included the determination of white blood cells, red blood cells, hemoglobin concentration, packed cell volume (PCV), mean corpuscular hemoglobin, fibrinogen, and platelet count using $\mathrm{ABC}$ Vet hematology analyzer (ABX Diagnostics, France). For serum biochemical parameters, blood urea nitrogen (BUN), creatinine, aspartate aminotransferase, and alanine aminotransferase were determined using commercially available kits.

\section{Statistical analysis}

Data are presented in means \pm standard error. All data were analyzed statistically using the Mixed procedure of SAS System for Windows Release 8.1 (2002, SAS Inst. Inc., Cary, NC) as repeated measures according to a completely randomized design. The model contained the effects of treatment, time, and interactions between treatment and time. Treatment means were computed using the LSMEANS option and separated using preplanned pairwise comparisons of least squares means using t-tests. Statistical difference was considered significant at $\mathrm{p}<0.05$.

\section{Results}

\section{MIC and MBC of sage EO}

The MIC of sage EO against $S$. aureus was determined to be $12.5 \%$ which equals to $120 \mathrm{mg}$ EO while the $\mathrm{MBC}$ was determined to be $6.1 \%$.

\section{Effects of sage EO on SCC}

SCC was decreased significantly at 24 and $48 \mathrm{~h}$ after treatment using both sage EO and amoxicillin (Table-1). In the sage EO group, SCC was $2000 \times 10^{3}$ cells $/ \mathrm{ml}$ at $48 \mathrm{~h}$ after the last treatment while it was $3400 \times 10^{3}$ cells $/ \mathrm{ml}$ before the treatment. In ewes treated with amoxicillin, SCC was $1500 \times 10^{3}$ cells $/ \mathrm{ml} 48 \mathrm{~h}$ after treatment compared to $2900 \times 10^{3}$ cells $/ \mathrm{ml}$ before the treatment. In the DMSO treated group, SCC actually increased slightly after administration.

\section{Effects of sage EO on milk constituents}

Milk fat and lactose were increased significantly in sage EO and amoxicillin treated ewes (Table-2). In sage EO and amoxicillin treated groups, fat percentages increased from 4.6 to 6.7 and from 5.9 to 7.5, respectively. While in DMSO, fat percentage did not change significantly.

In sage EO and amoxicillin treated groups, lactose percentages also increased significantly after treatment. Before treatment, lactose percentages were 3.8 and 3.3 in sage EO and amoxicillin treated groups, respectively. After treatment, lactose percentages increased to 4.5 and 4.4 in sage EO and amoxicillin treated groups, respectively.

Milk SNF percentages were not significantly increased in both sage EO and amoxicillin treated ewes. There were no significant changes in the percentages of SNF in DMSO treated groups.

SNF percentages increased from 8.7 to 9.4 and from 10 to 11 in sage EO and amoxicillin treated groups, respectively. No significant changes in the percentages of SNF in DMSO treated groups.

There were no significant effects on the percentages of protein and solids in milk of any of the treated groups.

\section{Effects of sage EO on hematology and serum bio- chemical parameters}

There were no statistically significant effects of sage EO treatment on any of the hematology or serum biochemical parameters tested in this study (Table-3).

\section{Side effects}

All sheep tolerated the intramammary infusion of sage EO very well. There were no local or systemic local effects noticed in any of the treated ewes.

Table-1: Effects of intramammary infusion of sage EO on milk somatic cell count $\left(\times 10^{3}\right.$ cells $\left./ \mathrm{ml}\right)$ in Awassi sheep affected with subclinical mastitis (mean \pm SD).

\begin{tabular}{lccc}
\hline Groups & \multicolumn{3}{c}{ Time of sampling } \\
\cline { 2 - 4 } & T0 & T24 & T48 \\
\hline Sage EO & $3400 \pm 570^{1}$ & $1900 \pm 330^{2}$ & $2000 \pm 460^{2}$ \\
DMSO & $2600 \pm 150$ & $2900 \pm 567$ & $2800 \pm 345$ \\
Amoxicillin & $2900 \pm 350^{1}$ & $2000 \pm 547^{2}$ & $1500 \pm 590^{2}$
\end{tabular}

T0=Before treatment, $\mathrm{T} 24=24 \mathrm{~h}$ after treatment, $\mathrm{T} 48=48 \mathrm{~h}$ after treatment, $\mathrm{EO}=$ Essential oil, $\mathrm{SD}=$ Standard deviation, $\mathrm{DMSO}=$ Dimethyl sulfoxide. Different superscript numbers in a row are significant at $p<0.05$ 
Table-2: Effects of intramammary infusion of sage EO on various milk constituents (\%) in Awassi sheep affected with subclinical mastitis (mean \pm SD).

\begin{tabular}{|c|c|c|c|c|c|c|}
\hline \multirow[t]{2}{*}{ Group } & \multicolumn{2}{|c|}{ Sage EO } & \multicolumn{2}{|c|}{ Amoxicillin } & \multicolumn{2}{|c|}{ DMSO } \\
\hline & TO & T48 & TO & T48 & TO & T48 \\
\hline Fat & $4.60 \pm 0.80$ & $6.70 \pm 0.80 *$ & $5.90 \pm 1.0850$ & $7.50 \pm 1.00 *$ & $4.50 \pm 1.00$ & $6.10 \pm 1.00$ \\
\hline SNF & $8.70 \pm 0.17$ & $9.40 \pm 0.18$ & $10.00 \pm 0.60$ & $11.00 \pm 0.60$ & $8.80 \pm 0.60$ & $9.60 \pm 0.60$ \\
\hline Protein & $5.00 \pm 0.40$ & $4.10 \pm 0.40$ & $5.20 \pm 0.40$ & $5.80 \pm 0.40$ & $5.10 \pm 0.40$ & $5.00 \pm 0.40$ \\
\hline Lactose & $3.80 \pm 0.30$ & $4.50 \pm 0.30 *$ & $3.30 \pm 0.20$ & $4.40 \pm 0.20 *$ & $3.80 \pm 0.20$ & $3.80 \pm 0.20$ \\
\hline Solids & $0.80 \pm 0.04$ & $0.75 \pm 0.04$ & $0.80 \pm 0.05$ & $0.90 \pm 0.050$ & $0.80 \pm 0.05$ & $0.80 \pm 0.05$ \\
\hline
\end{tabular}

$\mathrm{SNF}=$ Solids-not-fat, $\mathrm{EO}=$ Essential oil, $\mathrm{SD}=$ Standard deviation, DMSO=Dimethyl sulfoxide. $* \mathrm{p}<0.05$ using repeated measures

Table-3: Effects of intramammary infusion of sage EO on selected blood hematology and serum biochemical parameters in Awassi sheep affected with subclinical mastitis (mean \pm SD).

\begin{tabular}{|c|c|c|c|c|c|c|}
\hline \multirow[t]{2}{*}{ Groups } & \multicolumn{2}{|c|}{ Sage EO } & \multicolumn{2}{|c|}{ Amoxicillin } & \multicolumn{2}{|c|}{ DMSO } \\
\hline & TO & T48 & TO & T48 & TO & T48 \\
\hline PCV (\%) & $24 \pm 0.70$ & $21 \pm 0.70$ & $26 \pm 0.90$ & $24 \pm 0.90$ & $27 \pm 0.90$ & $22 \pm 0.90$ \\
\hline $\mathrm{Hb}(\mathrm{g} / \mathrm{dl})$ & $8.70 \pm 0.30$ & $8.80 \pm 0.30$ & $9 \pm 0.40$ & $11 \pm 0.40$ & $9 \pm 0.40$ & $9 \pm 0.40$ \\
\hline WBC $\left(\times 10^{3} / \mu \mathrm{l}\right)$ & $7.70 \pm 0.50$ & $9.70 \pm 0.5$ & $7.70 \pm 0.80$ & $9.90 \pm 0.80$ & $7.6 \pm 0.70$ & $7.60 \pm 0.80$ \\
\hline Urea (mmol/L) & $4.80 \pm 0.50$ & $6.30 \pm 0.60$ & $6 \pm 0.80$ & $7 \pm 0.80$ & $6 \pm 0.80$ & $5.50 \pm 0.80$ \\
\hline Creatinine (mmol/L) & $113 \pm 18$ & $87 \pm 19$ & $173 \pm 25$ & $143 \pm 25$ & $103 \pm 25$ & $115 \pm 25$ \\
\hline AST (U/L) & $56 \pm 4.80$ & $62 \pm 5.00$ & $63 \pm 6.90$ & $46 \pm 6.80$ & $56 \pm 6.80$ & $62 \pm 6.80$ \\
\hline ALT (U/L) & $28 \pm 3$ & $23 \pm 3$ & $29 \pm 4$ & $33 \pm 4$ & $30 \pm 4$ & $22.60 \pm 4$ \\
\hline
\end{tabular}

$\mathrm{PCV}=$ Packed cell volume, $\mathrm{Hb}=$ Hemoglobin, $\mathrm{WBC}=$ White blood cells, $\mathrm{AST}=$ Aspartate aminotransferase, $\mathrm{ALT}=\mathrm{Alanine}$ aminotransferase, $\mathrm{EO}=$ Essential oil, $\mathrm{SD}=$ Standard deviation, $\mathrm{DMSO}=$ Dimethyl sulfoxide

However, the effect sage EO on milk culinary characteristics and milk withdrawal times were not determined in this study.

\section{Discussion}

The EO of sage has proven in vitro antibacterial effects against certain important bacteria causing mastitis in ruminants such as $E$. coli and S. aureus [7]. The mechanism of this antibacterial effect was suggested to be due to the active component in Sage 1, 8-cineole [7]. The active component 1,8 -cineole in sage is believed to exert strong hydrophobicity effect on microbial cell wall, and mitochondria leading to leakage of cell contents and ultimately cell death [8]. Although among many other medicinal plants, sage has been used for a long time as an alternative to synthetic drugs for many purposes such as anti-inflammatory, antiseptic, and antibacterial effects, still more scientific evidence and more research to evaluate in vivo antimicrobial activity of EOs are needed [14].

SCC is used to identify mastitis in ruminants and can be used to evaluate the effectiveness of various drug regimens including sage EO [15]. The normal range of SCC for sheep milk has been determined previously and is known to vary between $10 \times 10^{3}$ and $200 \times 10^{3}$ cells/ml [16]. In this study, SCC in sage EO and amoxicillin treated groups were significantly decreased indicating potential therapeutic effects of this plant against ovine mastitis. Review of recent literature concerning in vivo and in vitro effects of sage EO against various bacterial species indicates variable results. In one study, weak inhibitory zone of sage EO was reported which indicates poor antibacterial effect [17]. These results were further fortified later by other researchers who concluded that sage EO did not show any antimicrobial activity at the studied concentration [11].

On the other hand, other recent studies have proven potential antioxidant and anti-inflammatory activities of sage EO. In addition, sage EO was found to exert antimicrobial activity against Staphylococcus spp., and other microorganisms as reported by Baranauskiene et al. [18] and ViudaMartos et al. [19]. Variation in the results of different studies could be explained by variation in extraction techniques (alcoholic method vs. hydrodistillation method) and variation in the dilution methods and concentration of the active components of the EO [11].

Moreover, the effect of sage EO in vivo could be significantly different than that reported in vitro. This difference could be related to the $\mathrm{pH}$ in the media where the oil is supposed to exert its effects. For example, the $\mathrm{pH}$ of milk varies between 6.4 and 6.6, but in the case of an infection, it increases to $\mathrm{pH}$ of 7.4 [20]. For best results, lower $\mathrm{pH}$ such (5-6) is preferred for sage EO $[8,21]$.

Milk composition is an important technological and quality feature of the processed and raw products. Several, animal related such as breed, age, mammary gland health, lactation stage, and monumental factors such as nutrition and dietary composition are responsible for the variation in various 
milk composition concentrations. Furthermore, both clinical and subclinical mastitis have been associated with a significant effect on milk physical as well as chemical characteristics $[12,22]$. This scientific data regarding the effect of mastitis on various milk components is variable, however. In general, mastitis may result in an increase in the level of proteinous compounds associated with the inflammatory and immune response such as albumin and immunoglobulins and a decrease in the endogenous milk proteins such as caseins $[23,24]$. There is also a decrease in the level of lactose and fat due to impaired synthesis [23]. In this study, the percentages of milk fat and lactose increased significantly after treatment of the udder using sage EO indicating a possible improvement in the udder health and milk quality. This was also noticed in ewes treated using a conventional antibiotic treatment which further indicates the effectiveness of this alternative therapy against ovine mastitis.

\section{Conclusion}

The intramammary administration of sage EO to ewes affected with subclinical mastitis in this study resulted in a significant decrease in SCC $24 \mathrm{~h}$ and $48 \mathrm{~h}$ post administration. In addition, milk fat and lactose were increased in animals that received the EO as well as in those treated with the antibiotic. Further, clinical trials are warranted to determine safety and possible withdrawal times in milk before its recommendation for use in organic operations.

\section{Authors' Contributions}

MOA: design the experiment, organizing the experimental work; samples collection and laboratory work. Data interpretation and paper writing. ZBI: Data analysis and interpretation. Editing the paper. MSA: Statistical analysis, help in reading and interpreting the data. Paper editing. SS: samples collection and the perform the lab work, help in paper drafting. All authors read and approved the final manuscript.

\section{Acknowledgments}

This study was sponsored by the Deanship of Research at Jordan University of Science and Technology grant no. 131/216.

\section{Competing Interests}

The authors declare that they have no competing interests.

\section{References}

1. Lu, Y., Hu, X.F., Kong, Y.L. and Wang, D.Y. (2008) Selection of component drug in activating blood flow and removing blood stasis of Chinese herbal medicinal formula for dairy cow mastitis by hemorheological method. J. Ethnopharmacol., 116: 313-317.

2. Dhakal, K., Tiezzi, F., Clay, J.S. and Maltecca, C. (2016) Causal relationships between clinical mastitis events, milk yields and lactation persistency in US Holsteins. Livest. Sci., 189: 8-1.

3. Menzies, P.I. and Romanoon, S.Z. (2011) Mastitis of sheep and goats. Vet. Clin. North Am. Food. Anim. Pract., 17: 333-358.

4. Gao, J., Yu, F.Q., Luo, L.P., He, J.Z., Hou, R.H., Zhang, H.Q., Li, S.M., Su, J.L. and Han, B. (2012) Antibiotic resistance of Streptococcus agalactiae from cows with mastitis. Vet. J., 194: 423-424.

5. Baskaran, S.A., Kazmer, G.W., Hinckley, L., Andrew, S.M. and Venkitanarayanan, K. (2009) Antibacterial effect of plant-derived antimicrobials on major bacterial mastitis pathogens in vitro. J. Dairy Sci., 92: 1423-1429.

6. Nurdin, E., Amelia, T. and Makin, M. (2011) The effects of herbs on milk yield and milk quality of mastitis dairy cow. J. Indones. Trop. Anim. Agric., 36: 104-108.

7. Lil, L.Z., Yin, Z., Wei, Q., Jia, R.Y., Zhou, L.J. and Peng, L.C. (2014) Antibacterial activity of leaf essential oil and its constituents from Cinnamomum longepaniculatum. Int. J. Clin. Exp. Med., 7: 1721-1727.

8. Burt, S. (2004) Essential oils: Their antibacterial properties and potential applications in foods-a review. Int. J. Food Microbiol., 94: 223-253.

9. Courvallin, P., Leclerq, R. and Bingen, E. (2006) Antibiogramme. $2^{\text {nd }}$ ed. ESKA, Paris, France. p163-177.

10. Byung-Wook, C., Chun-Nam, C., Soo-Mi, L., MeeJeong, K., Ju-Yeon, P., Chang-Yeol, Y., Song-Ee, S., Suk, K. and Hu-Jang, L. (2015) Therapeutic select of oregano essential oil on subclinical bovine mastitis caused by Staphylococcus aureus and Escherichia coli. Korean J. Vet. Res., 55: 253-257.

11. Dal Pozzo, M., Santurio, D.F., Rossatto, L., Vargas, A.C., Alves, S.H., Loreto, E.S. and Viegas, J. (2011) Activity of essential oils from spices against Staphylococcus spp. Isolated from bovine mastitis. Arq. Bras. Med. Vet. Zootec., 63: $1229-1232$.

12. International Dairy Federation, IDF. (1999) Suggested interpretation of mastitis terminology. Bulletin of International Dairy Federation No. 338. International Dairy Federation, Brussels, Belgium. p3-20.

13. Hagnestan, N.C., Emanuelson, U., Berglund, B. and Strandberg, E. (2009) Relationship between somatic cell count and milk yield in different stages of lactation. J. Dairy Sci., 92: 3124-3133.

14. Sfeir, J., Lefrançoism, C., Baudoux, D., Derbré, S. and Licznar, P. (2013) In vitro antibacterial activity of essential oils against Streptococcus pyogenes. Evid. Based Complement. Alternat. Med., 2013: 1-9.'

15. Baştan, A., Salar, S., Acar, D.B., Demirel, M.A., Cengiz, M., Darbaz, I. and Bulut, G. (2015) The effects of dry-off therapy on milk somatic cell count in Saanen goats. Turk. J. Vet. Anim. Sci., 39: 550-555.

16. Paape, M.J., Poutrel, B., Contreras, A., Marco, J.C. and Capuco, A.V. (2001) Milk somatic cells and lactation in small ruminants. J. Dairy Sci., 84: E237-E244.

17. Pașca, C., Mărghitaș, L.A., Dezmirean, D., Bobiș, O., Bonta, V., Mărgăoan, R. and Fit, N. (2015) The assessment of the antibacterial activity of some plant extracts on normal and pathogenic microflora from milk. Sci. Pap. Anim. Sci. Biotechnol., 48: 166-172.

18. Baranauskiene, R. (2007) Essential oil composition of Valeriana officinalis ssp. Officinalis grown in Lithuania. Chem. Nat. Compd., 43: 331-333.

19. Viuda-Martos, M., Ruiz-Navajas, Y., Fernández-López, J. and Pérez-Álvarez, J. (2008) Antibacterial activity of different essential oils obtained from spices widely used in Mediterranean diet. Int. J. Food Sci. Technol., 43: 526-553.

20. Ziv, G. (1980) Drug selection and use in mastitis: Systemic versus local drug therapy. J. Am. Vet. Med. Assoc., 176: 1109-1115.

21. Gutierrez, J., Barry-Ryan, C. and Bourke, P. (2008) The antimicrobial efficacy of plant essential oil combinations and interactions with food ingredients. Int. J. Food Microbiol., 124: 91-97.

22. Østerås, O., Solbu, H., Refsdal, A.O., Roalkvam, T., 
Filseth, O. and Minsaas, A.J. (2007) Results and evaluation of thirty years of health recordings in the Norwegian dairy cattle population. J. Dairy Sci., 90: 4483-4497.

23. De Olives, A.M., Díaz, J.R., Molina, M.P. and Peris, C. (2013) Quantification of milk yield and composition changes as affected by subclinical mastitis during the current lactation in sheep. J. Dairy Sci., 96: 7698-7708.

24. Bardhan, D. (2013) Estimates of economic losses due to clinical mastitis in organized dairy farms. Indian J. Dairy Sci., 66: 168-172.

$* * * * * * * *$ 